\title{
Kommentar
}

\author{
af Sune Johansson
}

\section{Konstruktiv kritik af Bredsdorffs konstruktivisme-kritik}

Lektor og forskningsbibliotekar ved Roskilde Universitetsbibliotek, Nils Bredsdorff, har skrevet bogen Diskurs og konstruktion - en samfundsvidenskabelig kritik af diskursanalyser og socialkonstruktivismer (2002). Som det fremgår af titlen er formålet at kritisere socialkonstruktivismen og diskursanalysen. Det er al ære værd at ville bidrage til den samfundsvidenskabelige debat i Danmark vedrørende diskursteori og socialkonstruktivisme. De få forsøg, der har været på at få en debat i gang, har ofte udviklet sig til at lejrene har dækket sig ind bag, at kritikerne kommer fra en anden forskningstradition og derfor ikke har den faglige indsigt, så de kan levere relevant kritik der er værd at lytte til. Bredsdorffs bog skriver sig ind i et felt/ en situation hvor der i mange år har været hårde kampe om hvorvidt fx socialkonstruktivistisk og kvalitativ forskning var rigtig videnskab. I de mest ekstreme tilfælde er konflikten imellem de forskellige positioner blevet kaldt "Science Wars", hvor man fra begge sider ihærdigt har forsøgt at svine den anden side til med grove beskyldninger og ved hjælp af uhæderlige metoder har man forsøgt at vise, hvor ukyndige den anden side er. Det mest kendte eksempel er den såkaldte Sokal-affære som Bredsdorff selv tager afstand fra i bogen, hvor Alain Sokal fik en fup-artikel trykt $i$ et anerkendt tidsskrift for derefter at hænge alle inden for den pågældende forskningstradition ud som dårlige videnskabsfolk.

Desværre for Bredsdorffs analyse og kritik har han set sig så gal på de ovennævnte teorier at kritikken bliver for nedladende og destruktiv, hvilket den spirende debat bliver ødelagt af. Dog er bogen stadig et udmærket oversigtsværk hvis man har brug for encyklopædiske definitioner af diverse begreber.

Der er ingen tvivl om at Bredsdorff kan sine klassikere (og mange andre) og hæger om de samfundsvidenskabelige idealers integritet. Det er blot ærgerligt at man efterlades med det indtryk (dvs. en ikke-videnskabelig konklusion - en hverdagsagtig betragtning), at han forsøger at tage patent på sandheden og nedgøre alle andre der har en anden opfattelse end ham og hans meningsfæller. Hele bogen er gennemsyret af en insinu- 
erende undertone der konspiratorisk lægger op til, at socialkonstruktivister og diskursteoretikere er ude på at søle den ægte videnskab til, mens de selv surfer af sted på en for ham fuldstændig uforståelig popularitetsbølge:

Disse konstruktivistiske principper skal tages op her, fordi mit forslag til at fjerne det mørke, som postmoderne modeluner har sænket over det videnskabelige samfund er kritik og kritik og kritik og dermed kan ligne Wennebergs forslag til forskningsdesign (Bredsdorff 2002:84).

Bogen er bygget op af fire kapitler, hvor kapitel 1 er introducerende (hvad betyder begreberne), kapitel 2 er bredt orienterende (socialkonstruktivismernes udvikling og sammenfletning med diskursanalysen), kapitel 3 er et forsøg på at uddybe hvad den samfundsvidenskabelige diskursanalyse handler om og i kapitel 4 gøres et forsøg på at konkretisere kritikken ved at der tages fat på en enkelt diskursanalytisk retning, som repræsenteres af bl.a. Jacob Torfings, Allan Dreyer Hansens og Torben Bech Dyhrbergs Laclau-inspirerede diskursteoretiske arbejde (der i øvrigt er langt mere omfattende end det marginale udsnit Bredsdorff anvender i sin analyse). I de tre første kapitler, der virker som de mest gennemarbejdede, præsenteres læseren for de problemstillinger Bredsdorff finder relevante at belyse, såsom problemer med at fastslå hvad diskursteori og -analyse egentlig er, problemer med relativisme og forståelsen af hvad det er der konstrueres socialt, samt problemer med at vurdere validitet, reliabilitet og generel videnskabelig kvalitet af diskursteoretiske arbejder. I det fjerde kapitel kaster Bredsdorff sig ud i en kritik der i bedste fald kan betegnes som ensidig og baseret på et for løst grundlag og i værste fald som værende manipulerende og ringeagtende. Bredsdorff beskriver i et voldsomt sprogbrug, hvordan han fx mener de konkret omtalte forskere fremturer med luftige ideer i enestående udokumenteret grad, at de kommer med "foucaultske dumsmarte bemærkninger" og at de er upålidelige (side 167). Konklusionen på bogen er at diskursteorien intet har at gøre med videnskab, men tilsyneladende giver "studerende og forskere et politisk emblem eller identitet i en usikker tid" (Bredsdorff 2002:183).

I det følgende vil jeg forsøge at fordrive de spøgelser Bredsdorff ser gå gennem den samfundsvidenskabelige verden og pirke lidt til den kritik der rejses. Bl.a. ved at henvise til steder i Bredsdorffs eget værk hvor han gør fuldstændig, som han i fejende vendinger kritiserer andre for fejlagtigt at gøre. Resten af min kommentar er bygget op gennem nedslagspunkter i bogen hvor NB gør præcis som han kritiserer andre for at gøre, men samtidig så bruges de rent konkrete eksempler til løbende at diskutere de mere overordnede erkendelses- og videnskabsteoretiske betragtninger der rejses i min kritik af kritikken.

Fx skriver han at den "diskursteoretiske digtning ikke er kritiserbar (...) fordi den kildemængde, hvorudfra monumenterne vælges og de regler, hvorefter udvælgelsen foregår, er uigennemskuelige og elastiske“1 . (op.cit.:180) Ikke et eneste sted i sin bog argumenterer Bredsdorff tilstrækkeligt for grundene til at han netop benytter sig af de kilder han gør. Ej heller kommer han ind på de kilder han har udeladt og begrundelserne for udeladelsen. Fx er der i bogen en omfattende brug af alle mulige encyklopædiske værker som forfatteren ikke redegør for relevansen af. Det eneste man får at vide er at han vil "forsøge" "at spore (diskurs-, red.) begrebets udvikling ved at opsøge 
diverse ophobninger af sikker encyklopædisk viden" (op.cit.:10). Her er der virkelig tale om en uigennemskuelig udvælgelse af kilder med høj grad af elasticitet i udførelsen. Især når ca. 2/3 af bogen er baseret på denne skøjten igennem diverse mere eller mindre obskure opslagsværker og lærebøger og først til sidst behandler enkelte kortere primær-værker. Med hensyn til de kilder han har undladt at bruge, men ikke fortalt os andre om, kan jeg nævne to af mine egne favoritter der med held kunne have været inddraget. Den ene er Umberto Eco der om nogen anden sprogteoretiker har beskæftiget sig med kulturens og de sociale relationers indvirken på fortolkningen af tegn, og den anden kilde er March \& Olsen der må siges at være rimeligt prominente socialkonstruktivister inden for samfundsvidenskaben. De sidste er sikkert ikke taget med fordi de generelt er accepteret som repræsentanter for "god" samfundsvidenskab, men hos $\mathrm{M} \& \mathrm{O}$ kan man fx læse at

Institutional theories similarly emphasize the ways in which institutions shape the definition of alternatives and influence the perception and the construction of the reality within which action take place (March \& Olsen 1995:29).

Der er selvfølgelig forskel på nyinstitutionel teori og diskursteori, men socialkonstruktivismen, der i bogen får skylden for at være ondets rod, er fælles gods.

NB skriver at ingen selvfølgelig vil bestride rigtigheden af, at der er historisk betingede rammer og begreber for erkendelse, og at det ikke er til at sige hvornår afdækningen af ideer og begreber er endelig, men han vil ikke tage skridtet fuldt ud. Fx mener han at sociale problemer ikke kun kan være socialt konstruerede, så man kan udlede at han mener de bliver nødt til at have en kerne, der afspejler reelle og virkelige problemer, som gør ondt på rigtige og virkelige mennesker og som man videnskabeligt kan finde frem til essensen af.

NBs problem er et pseudoproblem i en socialkonstruktivistisk kontekst, i det mindste sådan som jeg tolker socialkonstruktivismen. Hvad enten sociale problemer er konstruerede eller ej, så er de sociale problemer som man skal/kan forholde sig til. Hvordan man så forholder sig til disse problemer, er et spørgsmål om interaktion med andre mennesker og de relationer man indgår i. Sulten i Paris eksisterede også selv om Marie Antoinette ikke vidste noget om det, og da hun så endelig hørte om det men overhovedet ikke kunne sætte sig ind i brødmanglen, foreslog hun at de da bare kunne spise kager. Historien skulle efter sigende i øvrigt slet ikke være sand. Kan den så i det hele taget anvendes som eksempel?

De konstruktivister, jeg har beskæftiget mig med (fx Berg 2000; Berger \& Luckmann 1996; Bijker 1995)², betvivler på ingen måde virkeligheden eller folks ret til at mene at noget er mere rigtigt end noget andet. I virkeligheden er det et meget lille antal forskere der har sådanne radikale holdninger, og de går i følge Søren Kjørup under betegnelsen socialkonstruktionister (med "on" i stedet for " $\mathrm{v}$ " - se fx Kjørup 2001, som i øvrigt af NB tages til indtægt for at kritisere al socialkonstruktivisme, selv om Kjørup eksplicit i sin artikel giver udtryk for hvor vigtig denne skelnen er, og at han i øvrigt selv filosofisk kan tilslutte sig et grundlæggende konstruktivistisk standpunkt). Det socialkonstruktivister ser som kernen er, at graden af vished kan diskuteres samt at fællesskabet (igennem relationer og interaktion) spiller en afgørende rolle for meningsdannelse og adfærd i virkeligheden. 
Jeg er helt sikker på at jødeudryddelserne fandt sted, selv om revisionister forsøger at fortælle mig noget andet og selv om jeg ikke har set det selv, men fordi dem jeg stoler på i fællesskabet siger, skriver og på andre måder viser at det er rigtigt. Jeg er ret sikker på at hovedpinepiller hjælper på min hovedpine, og jeg er næsten sikker på at S-tog kører efter en tidsplan (frit efter Eco 1992).

Bredsdorff kører ud af nogle urimelige tangenter i sin fortolkning af diskursteorien og socialkonstruktivismen. Hver gang ender det med at handle om hvorvidt man nu også tror på den virkeligt virkelige virkelighed eller ej, og om sandheden er derude.

Der er bl.a. en fremstilling af en "radikal konstruktivistisk tilgang", hvor relativismeanklagen afvises med henvisning til "vi befinder os jo altid indenfor en bestemt diskurs, der forsyner os med mere eller mindre faste og entydige kriterier for, hvad der er sandt og falsk" (Dyrberg et al. 2000:334f), hvorfor der konkret kan tages stilling til, om A eller B er sand, dvs. konkret historisk sand. Men det er blot at flytte diskussionen et led længere ud med samme spørgsmål ubesvarede: Findes der sådanne ikke-teoriafhængige fakta; er der en historisk basisvirkelighed, "ting, hændelser", at relatere sig til, eller er der ikke? (Bredsdorff 2002:152)

Bredsdorff kommer aldrig selv med en éntydig melding på det spørgsmål, men gemmer sig bag en mur af løsrevne citater fra diverse opslag. Det skinner dog igennem at han mener, en sådan historisk basisvirkelighed findes og kan beskrives éntydigt, om end ikke objektivt, så dog intersubjektivt.
Grundlæggende handler det om retten til at udfordre en given fortolkning af tingenes tilstand og til at være på vagt over for det éntydige, der synes at kunne lede til totalitær undertrykkelse af anderledes tænkende ${ }^{3}$. Fx forekommer udsagn som det nedenfor yderst problematisk og lukkende sig om sig selv 4 .

Jeg har argumenteret for, at der kun findes een mulighed for analyse af den forvaltningspolitiske udvikling, den "traditionelle" historiske (Bredsdorff 1996:124).

Nils Bredsdorff har jo selv, i sin tid som formand for Greenpeace, prøvet lidt af den medicin som han her lader andre smage, hvor det han mener er "facts" blev udfordret af Bjørn Lomborg der har fremført, at vi i hans undersøgelse har at gøre med videnskabelige facts. Tallene taler deres tydelige sprog og de taler sand $t^{5}$. Lige meget hvor meget dokumentation NB og udvalgene vedrørende videnskabelig uredelighed er kommet med, og lige meget hvor meget de synes at kunne påvise at hans arbejde er i strid med god videnskabelig skik, så er der stadig (som det er blevet så ofte før) stillet et kæmpe spørgsmålstegn ved de eksakte videnskabers evne til entydigt at kunne sige noget sandt om virkeligheden. Derfor bør der være plads til at anerkende den epistemologiske anden ordens analyse der kan sige noget om konstruktionen af $\mathrm{fx}$ videnskabelige facts og ikke kun analyser, der spørger efter hvad tingene er. Det kan godt være at videnskaben dermed sidestilles med tro, håb, politik og kærlighed, men hvorfor skal vi være bange for det? Det virker som om han er bange for, at overtroen igen vil komme til at dominere samfundsudviklingen som i den mørke middelalder, hvis videnskaben ikke har forrang. Det er NBs henvisninger til det mørke, som har sænket sig 
over samfundsvidenskaben, som giver associationer til noget med middelalder (eller var det konnotationer). Der skal ikke herske tvivl om at jeg heller ikke ønsker mig middelalderlige tilstande, med pest og despoti (som videnskaben jo i øvrigt langt fra er lykkedes med at fjerne), men derfra og så til at lægge hele ansvaret for at undgå den udvikling over på videnskaben er for snæversynet, storsnudet og elitært.

Videnskaben er en multi-facetteret institution der bidrager til samfundsudviklingen og tilbyder indsigt og overblik på en lang række områder. Den adskilles fra områder som kultur og politik gennem adfærd der af fællesskabet anerkendes som videnskabelig. Både internt imellem videnskabsfolk og eksternt blandt lægfolk og bevilgende myndigheder/parter er der en række validerende overenskomster i form af regler og normer for hvad der er god og ægte videnskab, både i forhold til de resultater der produceres, og måden de produceres på. En af de mest betydningsfulde normer omhandler forskningsfriheden, en anden norm omhandler retten til og muligheden for at kunne udøve kritik.

Bredsdorff går for tæt på grænserne af disse normer. For det første kommer han i sin kritik til at gå mere efter manden end efter bolden og for det andet respekterer han ikke andre forskeres frihed til at afsøge forskellige forsknings-/ analysestrategier.

Sådan som jeg læser NBs kritik, når sarkasmen og insinuationerne er sorteret fra, så er der især tre områder han finder kritisable.

1. For det første mener han at kontingensen (tilfældigheden/vilkårligheden) udstrækkes til at være grænseløs (dvs. at alt er muligt).

2. For det andet at konstruktionsbegrebet gøres absolut (dvs. at alt er socialt konstrueret).
3. For det tredje, at socialkonstruktivisterne unddrager sig kritik og dermed mulighed for teoretisk udvikling ved at bruge for løst definerede begreber ( $f x$ socialkonstruktivisme og diskurs) og gennem inkonsekvent/usystematisk brug af disse.

For det første er alt ikke muligt, ifølge diskursteori, idet adfærd, begivenheder, ting og væsener befinder sig, udføres eller foregår i et mulighedsrum der bl.a. er afhængigt af diskursen. Diskursteorien skelner imellem tilfældighed (accidens) og kontingens (Torfing 2002), således at tilfældighed anses for at være noget der ikke er afhængigt af et mulighedsrum, mens kontingens afgrænses af de mulige udfald i et politisk-, socialt- og historisk mulighedsrum. Der kan således godt være tale om at kontingens spiller en rolle, men den er ikke grænseløs.

Det andet kritikpunkt er diskuteret ovenfor i forbindelse med diskussionen vedrørende facts og hvad der er virkelighed. Hverken Jacob Torfing eller Allan Dreyer Hansen, som NB eksplicit fremdrager i bogen, mener at alt er socialt konstrueret. Det kan være der er nogle socialkonstruktionister, der gør det. Det skal jeg ikke kunne udtale mig om. Væren er konstrueret, ikke eksistens.

Diskussionen om, hvor fast eller løst begreber kan defineres, har nok ingen ende. Indenfor sprog-teori kalder man et tegns sande betydning for tegnets denotation, mens de betydninger et tegn tillægges i den kulturelle kontekst, hvori de indgår, kaldes for konnotationer, men vis mig det tegn som ikke indgår i en kulturel/social kontekst! Man kan skrælle lag på lag af begrebers betydning, men nogen kerne kommer man nok aldrig ind til. Det er en af sprogets finurligheder at der skal være nogen at tale med - en kontekst. Hvis man ønsker at gå ind i en kritik af fx et forskningsfelt som diskursanalysen, må man altså gøre det ved at 
arbejde med de konkrete analyser, hvor man kan vise hvordan begreberne anvendes i fx forskellige kontekster. Man kan ikke på nogen meningsfuld måde tage udgangspunkt i encyklopædier eller ordbøger.

Bredsdorffs kritikpunkter fremtræder som værende for tilfældige, reduktionistiske og generaliserende. For det første trækker han tydeligvis kun på specifik viden om et par diskursanalyser, som han godt nok hævder er velmeriterede, men som han ikke har argumenteret for er eksemplariske cases (han håber kun de er det - Bredsdorff 2002:155). For det andet beskæftiger han sig mest med de dele af diskursteorien/konstruktivismen som er beskrivelser af, hvordan analyser udføres og ideerne bag. NB går kun sporadisk ned i selve analysen og fremdrager eksempler der lige præcis passer til hans fordomme ${ }^{6}$, uden at han - som han kritiserer andre for ikke at gøre - ekspliciterer disse. For det tredje over-generaliserer han. Selv om han ofte fremhæver den store forvirring og sammenblanding der eksisterer i feltet pga. alle dets mange forskellige retninger og udspring, så kan han alligevel ikke nære sig for at skære alle over en kam. Fx kan han finde på at skrive:

\footnotetext{
Diskursteorien har historisk bevæget sig fra at være kritik af de dominerende socialvidenskabelige retninger (historisk er diskursteorien også en humanistisk teori, red. $)^{7}$ hen imod tendentielt selv at blive dominerende og lukkende sig om sig selv $-i$ al fald ved adskillige universiteter. På den måde gentager diskursteorien den tragedie, den europæiske venstremarxisme gennemløb fra kritisk bombardement til bombastisk dogmatik i tresserne og halvfjerdserne. (s. 158).
}

Der er ingen tvivl om at mange socialkonstruktivister er tiltrukket af mulighederne for at køre ud på perceptionens og relativismens overdrev for at se, hvilken indsigt det vil give og der er heller ingen tvivl om at nogle forskere bruger socialkonstruktivisternes argumenter som undskyldning for ikke at være kildekritiske. Der er dog meget langt derfra og så til at udråbe en kæmpe gruppe mennesker, som driver seriøs samfundsvidenskabelig forskning, til at være charlataner der kaster samfundsvidenskaben ud i et middelalderligt mørke. Det er rent faktisk muligt at argumentere for at diskursteorien åbner sig mere og mere mod de øvrige etablerede videnskaber, idet der ved adskillige universiteter (for at blive $\mathrm{i}$ Bredstorffs ordvalg) er en stigende grad af interaktion imellem de forskellige fagtraditioner.

Her skal i øvrigt endnu en gang fremdrages et eksempel hvor Bredsdorff gør præcis det, han kritiserer andre for. Et sted $\mathrm{i}$ analysen af Torfings forskning (Bredsdorff 2002:169) gør NB opmærksom på at Torfing modsiger sig selv, hvilket gør at man ikke kan etablere en intersubjektiv $^{8}$ kontekst, som kan danne grundlaget for den nødvendige kritik. Jeg synes nu godt man kan kritisere Bredsdorffs arbejde alligevel, selv om han modsiger sig selv: Det ene sted hedder det sig at socialkonstruktivismen kun er ved at vinde indpas i samfundsvidenskaberne, mens den det andet sted er ved at blive dominerende.

Socialkonstruktivismen i samfundsvidenskaberne er først nu ved at vinde tilstrækkeligt indpas til, at den kan fortjene encyklopædisk interesse. Et af de mest omfattende (og kvalificerede) danske samfundsvidenskabelige opslagsværker (1996 og 2 . udg. 2000) $)^{9}$ har ikke noget opslag på 
socialkonstruktivisme (-ionisme)

(op.cit.:67)

og

Enhver teoretisk skole (i dette tilfælde den politologiske diskursteori, som er en del af de(n) stærke relativistiske eller socialkonstruktivistiske position(er), red.), der truer med at blive dominerende og eksklusiv, bør naturligvis tages under behandling (op.cit.:157).

Selv om overfortolkning helt sikkert har en værdi, så er der, som også Umberto Eco (1992) siger (hvilket Bredsdorff i øvrigt selv har citeret ham for ${ }^{10}$ ), grænser for fortolkning. Man bliver nødt til at interagere med det kulturelle og sociale skatkammer og acceptere skribentens kulturelle og lingvistiske baggrund i sin fortolkning for at lave en ordentlig analyse. I Bredsdorffs bog er der ingen forsøg på interaktion eller accept af udgangspunktet og derfor slipper han heller ikke særlig godt af sted med sin kritik. Til slut vil jeg bringe et par citater fra to personer, som jeg ved Bredsdorff anser for at være hæderlige fagfolk, og som bidrager konstruktivt til den samfundsvidenskabelige erkendelses-diskussion.

To say that there is no Ding an Sich and that our knowledge is situational, holistic and constructive does not mean that when we are speaking we are not speaking of something. To say that this something is relational does not mean we are not speaking of a $g i$ ven relationship. Undoubtedly, the fact that our knowledge is relational and that we cannot separate facts from the language by means of which we express (and construct) them, encourages inter- pretation. I agree with Culler that even overinterpretation is fruitful, I agree with the idea of hermeneutic suspicion, I am convinced that the fact the Three Little Pigs are three and not two or four is of some purport (Eco, 1992).

Hvis videnskab bare gik ud på at formulere sande påstande, ville det være en af de letteste aktiviteter i verden. Det der gør det så besværligt er at man også skal begrunde påstandene - og at også begrundelserne skal være holdbare og overbevisende (Kjørup 1989).

De to ovenstående citater opsummerer på fornemmeste vis mit udgangspunkt i vurderingen - og min kritik af Bredsdorffs arbejde. Bredsdorffs overfortolkning, lidet overbevisende og uholdbare begrundelser for kritikken af diskursteorier og socialkonstruktivismer skal dog have en konstruktiv afskedssalut med på vejen: Arbejdet med bogen har givetvis bidraget til styrke forfatterens identitet "i en usikker tid", lige som han mener diskursteorien har gjort det for forskere og studerende der beskæftiger sig med denne teori (se tidligere i denne kommentar). Det at konstruere en dem-og-os-dikotomi, som Bredsdorff er lykkedes med i denne bog, er en klassisk måde at skabe identitetsfølelse på. Spørgsmålet som står ubesvaret tilbage er dog, om det har nogen betydning - og i så fald, hvilken for samfundsvidenskabernes udvikling? 


\section{Noter}

1. Bemærk den implicitte sarkasme i Bredsdorffs brug af ordet "digtning" $\mathrm{i}$ omtalen af forskernes arbejde med kilderne og udvælgelsen af disse. På siden før "erkender" han at "den rigtige videnskab" også tyr til "digtning", men til forskel fra omtalen af diskurs-teoretikernes arbejde, så er ordet der sat i citationstegn.

2. For nu bare at tage et muligvis tilfældigt udpluk af dem der har B (som Bredsdorff) i deres efternavn.

3. NB påstår i sin bog, at det er den anden vej rundt (relativister baner vejen for det totalitære), fordi naive relativister ikke tør slå en streg i sandet, fx over for Nazisme, da alt jo ifølge dem har lige stor værdi.

4. Hvilket NB flere gange kritiserer socialkonstruktivismen og diskursanalytikerne for.

5. (se fx http:/ / www.greenspirit.com/lomborg/ScientificAmericanBjornLomborgAnswer.pdf.)

6. Det er faktisk kun i det sidste kapitel vi møder den konkrete diskursanalyse i form af et par arbejdspapirer som Jacob Torfing skrev i hhv 1999 og 2000. Torfing har en stor empirisk produktion bag sig, så det er ikke fordi der ikke er noget at vælge imellem, at NB netop vælger to arbejdspapirer. Man har lidt på fornemmelsen at han er offer for det han kritiserer andre for, at fravælge kilder fordi arbejdet med at gennemgå dem er for omfattende. Bl.a. er NBs argument for ikke at forfølge Torfings forskning yderligere, at det ligger uden for hans historiske forskningsfelt. Det er fuldstændig de samme fors kningspolitiske argumenter, i stedet for faglige argumenter, som han bruger meget tid på at kritisere de andre for at bruge i udvælgelsen af kilder.

7. Grunden til at jeg bryder sådan ind i NBs redegørelse for hvad diskursteorien er, er for at vise hvordan han endnu engang gør fuldstændig som han kritiserer andre for at gøre. Torfing skriver at kimene til socialdemokratiets fokusskift fra socialisme til velfærdsstat rent historisk blev lagt af en række skandinaviske økonomer. NB konkluderer efter at have bragt citatet af Torfing, at "rent historisk er det forkert". Jeg vil blot henlede opmærksomheden på at man kunne sige det samme om ovenstående citat.
8. Intersubjektivitet benyttes af NB som legitimeringsgrundlag i bedømmelsen af hvornår noget er rigtigt eller forkert. Der kan $\mathrm{i}$ høj grad stilles spørgsmålstegn ved om "intersubjektiviteten skyldes iboende egenskaber ved objektet" , hvilket er det der teoretisk skulle gøre intersubjektivitet lige så stuerent som objektivitet. Intersubjektivitet kan lige så godt skyldes tilfældige "sammenfald af perspektiver, egenskaber osv. hos de subjekter, der er tale om". (Dahler-Larsen 1997:95).

9. Heine Andersen og Lars Bo Kaspersen (red.), Klassisk og moderne samfundsteori, Hans Reitzels Forlag 2000.

10. I sin afhandling om Forvaltningshistorie og forvaltningsvidenskab, RUC 1996.

\section{Litteratur}

Berg, R. 2000: Den "gode" politiker - et studie af politiske ledelsesværdier $i \mathrm{kom}$ munerne. Odense: Odense Universitetsforlag.

Berger, P. L. \& Luckmann, T. 1996: Den samfundsskabte virkelighed: En videnssociologisk afhandling, Vol. 2. København: Lindhardt og Ringhof.

Bijker, W. E. 1995: Of Bicycles, Bakelites, and Bulbs. Toward a Theory of Sociotechnical Change. Cambridge: The MIT Press.

Bredsdorff, N. 1996: Forvaltningshistorie og forvaltningsvidenskab - en undersøgelse af efterkrigsårenes forvaltningshistorie og Forvaltningskommissionen af 1946. Unpublished Ph.D., Roskilde Universitetscenter, Roskilde.

Bredsdorff, N. 2002: Diskurs og konstruktion - En samfundsvidenskabelig kritik af diskursanalyser og socialkonstruktivismer. Frederiksberg: Forlaget Sociologi.

Dahler-Larsen, P. 1997: “Intersubjektivitet" . In M. N. Pedersen, K. Goldmann \& Ø. Østerud (eds.): Leksikon i Statskundskab. København: Akademisk Forlag. 
Eco, U. 1992: Interpretation and Overinterpretation. Cambridge: Cambridge University Press.

Kjørup, S. 1989: Forskning og samfund - en grundbog i videnskabsteori. København: Gyldendal.

Kjørup, S. 2001: "Den ubegrundede skepsis". Sosiologi i dag, 31(2), 5 - 22.

March, J. G. \& Olsen, J. P. 1995:Democratic Governance. New York: The Free Press.
Torfing, J. 2002: Antifundamentalisme og antiessentialisme, [WWW]. Dansk Center for Diskursteori. Available: http:/ /www.diskurs.dk/skaermkursus/ skaerm6.pdf [2002, 31. december 2002].

Sune Johansson

E-mail: sjo@ruc.dk 